\title{
Immunoregulation effects of TIM-3 on tumors
}

\author{
Minireview
}

\author{
C. C. SHENG ${ }^{1,2}$, F. Y. HAN ${ }^{1, *}$ \\ ${ }^{1}$ Department of Clinical Laboratory, The Second Hospital of Shandong University, Jinan, China; ${ }^{2}$ Department of Obstetrics and Gynecology, \\ Shanghai General Hospital of Shanghai Jiaotong University, Shanghai, China
}

*Correspondence: hanfuyan395@163.com

Received June 10, 2018 / Accepted September 12, 2018

\begin{abstract}
Cancer poses a serious threat to human health and its increasing incidence has made it one of the most common causes of death. Immune factors affect in vivo tumor cell survival and expansion, and cancer patients have obvious cell immune dysfunction and low anti-tumor immunity. TIM-3 can be widely expressed in a variety of immune cells and it affects both innate and adaptive immune response by regulating the function of immune cells, thus affecting tumor occurrence and development. This paper focuses on the TIM-3 regulation of immune cells, and its expression and mechanism in patients with liver, gastric and prostate cancers in order to explore its regulatory mechanism in tumor immunity and provide new ideas and targets for tumor immunotherapy.
\end{abstract}

Key words: TIM-3, immune cells, tumor immunity

\section{TIM-3 structure and ligands}

TIM-3. The gene family of $\mathrm{T}$ cell immunoglobulin and mucin-domain containing molecule (TIM) was a novel gene family identified by McIntire in the 2001 study of susceptibility genes for asthma in mice. This was identified by genome analysis and positional cloning [9]. TIM-3, also known as hepatitis A virus cellular receptor-2(HAVCR-2), is an important member of the TIM family [10]. The mouse TIM-3 gene is located on chromosome 11 and has 1,015 nucleotides, encoding 281 amino acids, whereas the TIM-3 gene in human is located on chromosome $5 \mathrm{q} 33.2$ and has 1,116 nucleotides encoding 301 amino acids [11]. The structure of the TIM-3 gene, like that of other gene-encoding proteins in this family, includes one signal peptide, one immunoglobulin $\mathrm{V}$ ( $\mathrm{IgV}$ )-like domain with cysteine, one mucin-like domain rich in threonine, serine and proline, the trans-membrane region and one cytoplasmic region with tyrosine kinase phosphorylation motifs. The IgV-like domain is most likely where TIM-3 interacts with its ligand, and the intracellular region contains a tyrosine phosphorylation motif and one SH2 domain which may be involved in signal transduction [12].
Ligands. The following four distinct ligands are currently reported to bind to Tim-3 in different contexts. These are galectin-9 (Gal-9), high-mobility group protein B1(HMGB1), carcino-embryonic antigen cell adhesion molecule 1 (Ceacam-1), and phosphatidylserine (PtdSer) [13].

Gal-9 was the first discovered TIM-3 ligand and its role as a ligand was identified by immuno-precipitation of cell surface proteins that bind to immunoglobulin domains in the TIM-3 molecule [14]. Gal-9 has a wide spectrum of expression and can be detected in a variety of cells and provide a negative stimulus signal for T cells after binding to TIM-3. This signal can down-regulate Th1 cell response, thereby mediating Th1 cell apoptosis $[15,16]$. In the non-activated immune system, Gal-9 is mainly expressed in resting $\mathrm{CD} 4^{+} \mathrm{T}$ cells and $\mathrm{CD}^{+} \mathrm{FoxP}^{+}$Treg cells, and while Gal-9 expression on effector T cells is decreased in T-cell activation, Treg cells consistently express it $[12,17]$.

HMGB1 is highly expressed on tumor-infiltrating DCs (TADC). Here, Tim-3 competes with nucleic acid binding to HMGB1 in tumors, and it lowers the transport of nucleic acids to the endosomes, thereby dampening the innate immune response to tumor-associated nucleic acid [18-20] (Figure 1B). 
Ceacam-1 is the most recently identified ligand for Tim-3, and it can form a heterodimer with Tim-3 or interact with it in trans form [13].

While PtdSer interaction with Tim-3 has a role in the clearance of apoptotic bodies and can contribute to antigen cross-presentation, it has the lowest affinity of the four most widely recognized ligands [21].

\section{TIM-3 expression and function}

TIM-3 and T cells. T cell-mediated cellular immunity is the main mechanism of in vivo anti-tumor immunity [22]. The cytotoxic $\mathrm{CD}^{+} \mathrm{T}$ cells (CTL) can be directly used as effector cells to specifically kill cancer cells, and it is very difficult for those to survive when the body produces sufficient CTL specific for tumor cells, [23]. Current studies show that exhausted $\mathrm{T}$ cells occur in human chronic viral infections and cancers, thereby losing cytotoxicity and the ability to proliferate and secrete cytokines including IL-2, TNF- $\alpha$ and IFN- $\gamma$ when stimulated by the antigen $[24,25]$. The TIM-3 expressed by $\mathrm{T}$ cells inhibits the tumor immune response especially by mediating $\mathrm{T}$ cell depletion or by promoting myeloid derived suppressor cell proliferation (MDSCs) [26, 27] (Figure 1B).
TIM-3 over-expression in clinical models and human cancers can be detected in peripheral lymphoid tissue, tumor infiltrating lymphocytes and T-cells in the blood [28]. TIM-3 and $\mathrm{PD}-1$ are also co-expressed in most exhausted $\mathrm{CD}^{+} \mathrm{T}$ cells and they synergistically induce T-cell depletion [28]. This suggests that blocking the TIM-3 and PD-1 signaling pathways is more effective in recovering the function of depleted $\mathrm{CD}^{+} \mathrm{T}$ cells and preventing and treating cancer than blocking these pathways individually [29].

In addition to $\mathrm{CD} 4^{+} \mathrm{T}$ cells regulation of tumor immunity [22], Th1 cells can secrete cytokines such as IL-2, IFN- $\gamma$ and TNF- $\alpha$ which promote cellular immunity by directly or indirectly activating macrophage and CTL and NK cell cytotoxicity and phagocytosis ability [2]. They therefore have very important roles in the body's anti-tumor immune response. Since Th1 cells are inhibited in advanced cancer patients, tumor immunotherapy should try to shift the Th1/ Th2 balance to Th1 [30].

Further, TIM-3 is a negative regulatory molecule which can induce Th1 cell apoptosis and shift Th1/Th2 balance to Th2 after binding to the Gal-9 ligand [31]. This negative TIM-3 regulatory signal on Th1 cells can be removed by blocking the TIM-3 signaling pathway with either TIM-3mAb or Tim-3 siRNA. The Th1/Th2 balance can then shift to Th1,
A

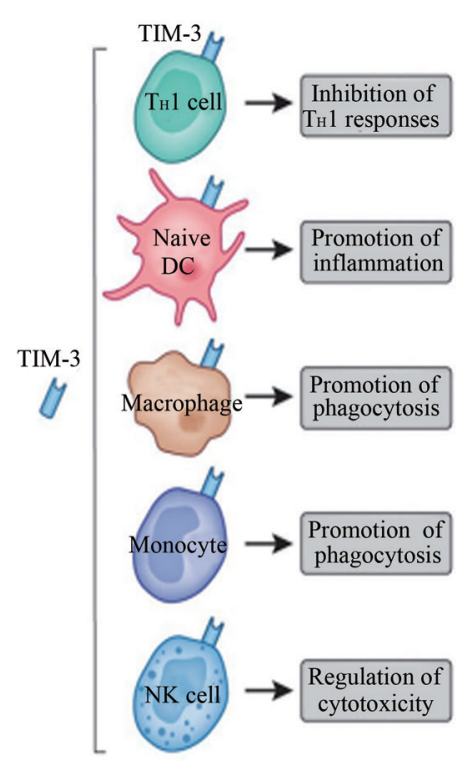

B
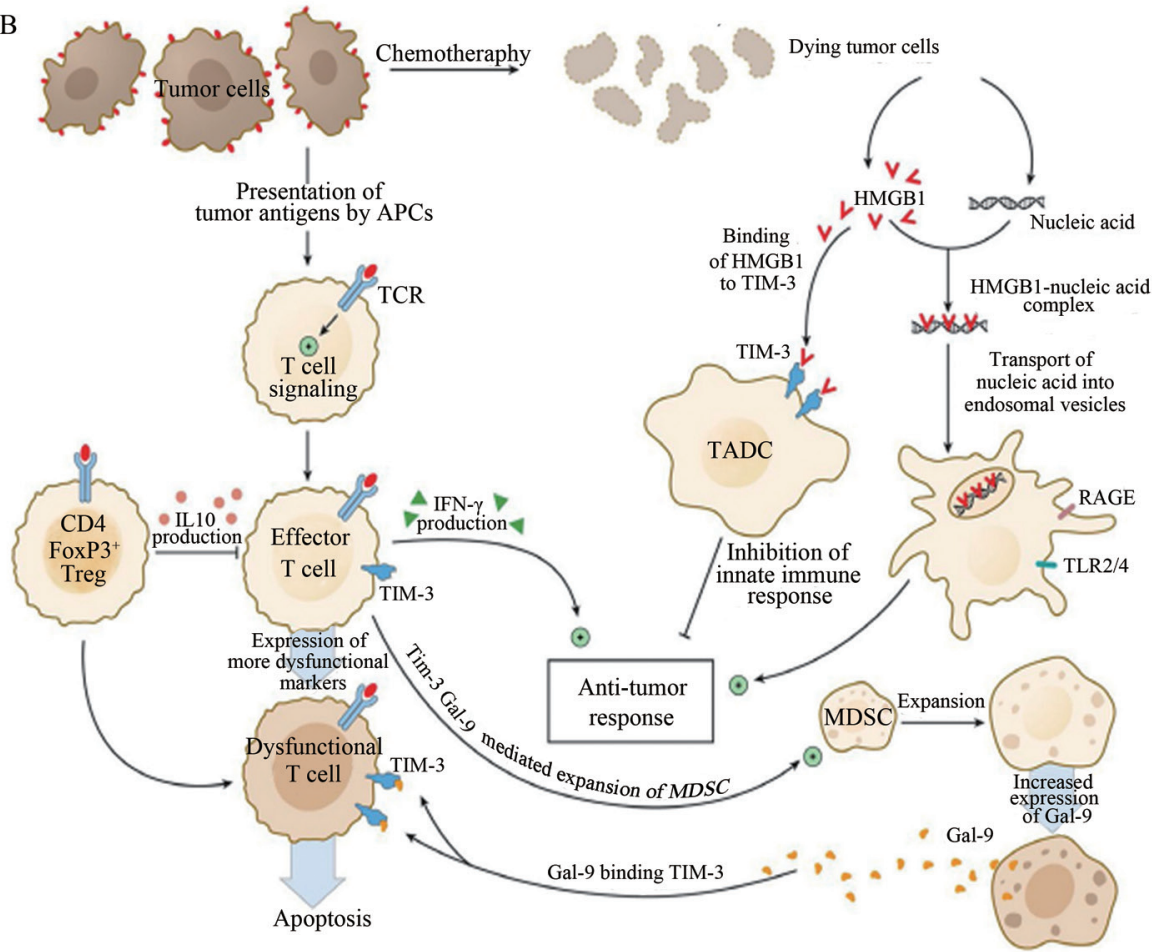

Figure 1. TIM-3 is a major regulator of tumor immunity. A) TIM-3 expression and function in various immune system cells. B) TIM-3 molecules expressed on the tumor-infiltrating DCs (TADC) bind to HMGB1 to block the transport of nucleic acids into endosomes, thereby suppressing patternrecognition receptor-mediated innate immune response to tumor-derived nucleic acids. Interferon- $\gamma$ production by effector $T$ cells promotes antitumor response but also drives expansion of myeloid-derived suppressor cells (MDSC). The latter produce increased Galectin-9 (Gal9) molecules which then bind to TIM-3 molecules expressed on TIM-3-expressing effector CD8+ T cells in the tumor micro-environment. This leads to effector T cell apoptosis. The Tim-3+FoxP3+ Tregs present in the tumor express high amounts of Treg effector molecules (IL-10, etc.) and inhibit effector T cells. 
thus enhancing the T-cell tumor immune response [30]. Yan et al. [32] showed that TIM-3 expression on $\mathrm{CD}^{+}{ }^{+} \mathrm{T}$-cells is up-regulated in cancer patients and this leads to impaired function of tumor-derived TIM- $3^{+} \mathrm{CD} 4^{+} \mathrm{T}$ cells secreting IFN- $\gamma$ and IL-2.

The TIM-3 signal pathway can also regulate $\mathrm{CD}^{+}{ }^{+}$FoxP3 ${ }^{+}$ regulatory $\mathrm{T}$-cells (Tregs), thereby inhibiting the immune response of Th1 cells [33]. Tregs immuno-suppressive function is the key to promoting tumor immune escape $[34,35]$. Large amounts of Tregs accumulate locally in the tumor and inhibit the anti-tumor effect of immune cells by secreting inhibitory cytokines such as IL-10 and TGF- $\beta$ [36] (Figure 1B). TIM-3 is specifically expressed in tumorassociated Tregs, where Gal-9 can promote their amplification through the TIM-3/Gal-9 pathway, but it can also reduce the number of TIM- $3^{+}$effector T cells (Teffs) by stimulating their apoptosis $[2,31,37]$. The TIM-3/Gal-9 pathway thus regulates tumor immune response by balancing Tregs and Teffs in the tumor micro-environment.

Hastings et al. [38] recently reported that TIM-3 is expressed in Th17 cells, and it also affected cytokines secretion in Th1 and Th17 cells. Since these cells have important roles in tumor immunity, it is possible to regulate Th17 by TIM-3, thereby modulating tumor immunity.

TIM-3 and macrophages. Macrophages are important innate immune cells and the first line of defense against infection. These cells can be polarized in $\mathrm{M} 1$ and $\mathrm{M} 2$ subgroups in different microenvironments where M1 activation promotes inflammation and inhibits tumors and M2 inhibits inflammation and promotes them.

The tumor-associated macrophage is the archetype of the M2 phenotype [40]. One study identified that TIM-3 is highly expressed in M2 macrophages and promotes their polarization; and inhibiting TIM-3 expression can restrain M2 polarization and promote it in M1 macrophages [41]. Moreover, TIM-3 CD $14^{+}$cell expression in peripheral blood and tumors is significantly increased in patients with primary hepatic carcinoma [42]. Zhang et al. [43] report that TIM-3 monocyte and macrophage expression acts as a negative regulator in immune response; and blocking antibodies and Tim-3 siRNA changes the TIM-3 signal pathway and promotes TAM secretion of pro-inflammatory cytokines, thereby enhancing anti-tumor immune response.

TIM-3 and dendritic cells. Dendritic cells (DCs) have important roles in anti-tumor immune response. They are activated by identifying nucleic acids released from tumor cells after chemotherapy [20]. The expression of TIM-3 on tumor-infiltrating DCs is significantly higher than on DCs in normal tissue, and the expression is earlier and higher than on $\mathrm{CD}^{+} \mathrm{T}$ cells [18]. TIM-3 in DCs preferentially interacts with nuclear protein HMGB1. This inhibits nucleic acid recruitment to DC inner chambers, thereby inhibiting signal transmission of innate immune response and this leads to increased tumor loading following chemotherapy [18, 20, 44, 45] (Figure 1B).

Previous studies have suggested that the interaction of TIM-3 and Gal-9 on antigen cells is beneficial in promoting DC maturation and cross-activation of tumor-specific T cells $[46,47]$. In contrast, TIM-3 expressed by tumor-infiltrating DCs promotes tumors and this can shut down the innate immune response mediated by nucleic acid by binding to HMGB1 rather than to Gal-9 $[18,44]$.

TIM-3 and endothelial cells. Endothelial cells have special effect on tumor cell hematogenous metastasis. Huang et al. [48] reported that TIM-3 is expressed on B cell lymphoma endothelial cells and that this expression is related to tumor metastasis and poor prognosis. TIM-3 expressed on endothelial tissue inhibits the response of $\mathrm{CD}^{+} \mathrm{T}$ cell rather than $\mathrm{CD}^{+} \mathrm{T}$ cells. In vitro, TIM- $3^{+}$endothelial cells inhibit the activation of $\mathrm{CD} 4^{+} \mathrm{T}$ lymphocytes by activating the IL-6-STAT3 pathway, thereby regulating the response of $\mathrm{T}$ cells to lymphoma antigens, inhibiting the polarization of Th1 cells and providing protective immunity for tumors. The lymphoma mouse model highlighted that TIM- $3^{+}$endothelial cells can promote the development, growth and metastasis of lymphoma by inhibiting the activation of $\mathrm{CD}^{+} \mathrm{T}$ cells and polarizing Th1 cells [48]. If TIM-3 expressed on tumor-associated endothelial tissue is a proven common feature of solid tumors, these studies will provide further powerful demonstration of TIM-3 as a new target for tumor immunotherapy.

TIM-3 and myeloid-derived suppressor cells (MDSCs). Although general research records that TIM-3 can directly inhibit $\mathrm{T}$ cell response by inducing cell death and exhaustion, one study reported that Tim-3 expression on $\mathrm{T}$ cells can indirectly inhibit the immune response by amplifying MDSCs $[2,27]$. It has also been shown that TIM-3 promotes MDSC proliferation by interacting with its galectin- 9 , thereby inhibiting $\mathrm{T}$ cell immune response and increasing poor tumor prognosis [49] (Figure 1B). Moreover, over-expression of TIM-3 on T cells inhibits their immune response and increases the number of MDSCs. Similarly, Gal-9 overexpression also promotes MDSC amplification and inhibits the immune response [27], and it is also reported that both tumor growth and MDSC amplification are relatively slow in TIM-3 deficient mice [50].

All these combined studies therefore confirm that the TIM-3/Gal-9 signaling pathway inhibits the immune response by modulating MDSC amplification.

\section{Synergism between TIM-3 and other negative check- point regulators}

It is currently accepted that tumors have dual check-point pathways for immune suppression. Studies report that the expression of negative TIM-3 and regulator programmed death-1 (PD-1) impairs cell-mediated immunity responses 
in advanced melanoma and colorectal cancer [51,52]. Co-blockage of TIM- 3 and PD- 1 can therefore enhance the expansion and function of tumor antigen-specific $\mathrm{CD}^{+} \mathrm{T}$ cells in vitro and in vivo, induce tumor rejection in experimental models and improve the vaccine effect in patients with advanced melanoma $[53,54]$.

New treatments targeting TIM-3 and PD- 1 on $\mathrm{CD}_{4}^{+}$ and $\mathrm{CD}^{+} \mathrm{T}$ cells could provide breakthrough treatment for cancer patients. Co-blockage of TIM-3 and CD137 in a murine ovarian cancer model increases the number of $\mathrm{CD}^{+}$and $\mathrm{CD}^{+} \mathrm{T}$ cells and decreases immunosuppressive $\mathrm{CD}^{+} \mathrm{FoxP}^{+}$regulatory $\mathrm{T}$ cells (Tregs) and $\mathrm{CD} 11 \mathrm{~b}^{+} \mathrm{Gr}-1^{+}$ MDSC, and thus prevents tumor progression [50]. Further, the co-blockade of carcino-embryonic antigen cell adhesion molecule 1 (CEACAM1) and TIM-3 leads to enhancement of anti-tumor immune response with improved tumor elimination in the mouse colorectal cancer model [55]. The expression of other negative check-point regulators on tumorinfiltrating lymphocytes, including cytotoxic $\mathrm{T}$ lymphocyte antigen-4 (CTLA-4), lymphocyte activation gene-3 (LAG-3) and BTLA (B and T lymphocyte attenuator) also negatively regulates immunity in tumor micro-environments. However, the mechanism of co-blockage with TIM-3 requires further investigation [56-58].

\section{TIM-3 and tumors}

TIM-3 and hepatocellular carcinoma (HCC). HCC is one of the most common global cancers with high morbidity and mortality [59], and the relationship between hepatocellular carcinoma and cellular immunity is a prime research topic because cellular immunity plays an important role in tumor development. Li et al. [4] showed that Tim-3 expression on CD4+ and CD8+ T cells in HCC is greater than in adjacent tissues. They added that TIM-3+ T cells are replication-senescent and express surface and genetic markers for senescence.

Functional studies have demonstrated that TIM-3/ galectin-9 signaling pathway blockade increases the functionality of tumor-infiltrating TIM-3+ T cells. This is shown by increased T-cell proliferation and effective cytokine production, and they also confirmed that the number of TIM-3+ tumor-infiltrating cells is negatively associated with patient survival. It has been speculated that TIM-3 is involved in anti-tumor immunity by $\mathrm{T}$ cells infiltrating tumor tissue during HCC development, and the mechanism may be that TIM-3 provides a negative regulation signal for Th1 cells by binding to Gal-9 and inducing Th1 cell apoptosis.

TIM-3 can also induce CD8+ $\mathrm{T}$ cells to become exhausted and lose proliferation and cytokine secretion, thus resulting in immune tolerance. Hume [42] found that TIM-3 modulates the innate immune response through macrophage polarization and halts liver cancer development and progress. Studies further revealed that TIM-3 gene polymorphisms have important roles in hepatocel- lular carcinoma characteristics, and susceptibility to it. The $-1616 \mathrm{G} / \mathrm{T}$ polymorphism in the TIM-3 promoter region is associated with these hepatocellular carcinoma characteristics, including tumor grade and lymph node metastasis. Patients with high tumor grade and lymph node metastases tend to have higher frequencies of genotype GG, TT and allele $\mathrm{T}[60]$. These studies shed light on the regulation of TIM-3 in innate and adaptive immunity and provide a new target in HCC immunotherapy.

TIM-3 and gastric cancer. Gastric cancer ranks fourth in most common cancers and the second leading cause of cancer-related deaths. Although its incidence and mortality have declined in European countries in recent decades, gastric cancer remains one of the most common cancers in China $[61,62]$.

Cheng et al. [5] used flow cytometry to detect the expression of TIM-3 in 52 patients with gastric cancer and 15 patients with gastritis. The results showed that $\mathrm{CD} 4+\mathrm{T}$ and CD8+ T cell TIM-3 expression in gastric cancer patients was significantly higher than that in those with gastritis. The expression of Tim-3 in CD4+ T cells was related to the depth of invasion, lymph node metastasis and TNM staging in gastric cancer, but in CD8+ T cells it was only related to the TNM stage. Results suggest Tim-3 has an important role in the invasion and metastasis and is an adverse prognostic factor in gastric cancer.

A further study found that TIM-3 gene polymorphisms were related to gastric cancer. Individual genotype analysis established that the $-1516 \mathrm{G} / \mathrm{T},-574 \mathrm{G} / \mathrm{T}$ and $882 \mathrm{C} / \mathrm{T}$ polymorphic loci of the TIM-3 gene promoter were associated with susceptibility to this cancer, and the $-1516 \mathrm{G} / \mathrm{T}$ locus promoted distant metastasis [63]. Jiang et al. [8] then recorded that the survival rate of patients with positive Tim-3 expression tumors was significantly lower than those with negative Tim-3 expression, and univariate and multivariate analysis confirmed that Tim-3 over-expression in tumor cells influenced poor gastric cancer prognosis.

TIM-3 and lung cancer. Lung cancer is the leading cause of cancer-related death worldwide. In China, the incidence of lung cancer has grown rapidly, resulting in great social and economic burden. The high mortality rate is primarily due to difficulty in diagnosing lung cancer in early stages and the rapid progression in later stages [64].

Ji et al. [65] indicated that the expression of TIM-3 on CD4+ TILs or CD8+ TILs in tumor tissues was significantly higher than on these cells in adjacent normal lung tissue. Moreover, TIM-3 expression on CD4+ TILs correlated with poor patient prognosis in non-small-cell lung cancer. Gao et al. [66] then reported that plasma exosomal TIM-3 was significantly higher in that cancer than in healthy samples, and high TIM-3 levels positively correlated with several malignant parameters, including larger tumor size, advanced stages and increased lymph node and distant metastases. 
TIM-3 and breast cancer. Breast cancer is the most common cancer globally diagnosed in women, and although treatment options have improved the overall 5-year $90 \%$ survival rate varies with individual response [67].

Shen et al. [68] determined that TIM-3 mRNA expression in tumor-infiltrating lymphocytes was significantly higher than in para-cancerous tissues. There were significant differences in TIM-3 mRNA expression in the tumor-infiltrating lymphocytes in different tumor histological grades, tumor size and lymph node metastasis. Cheng et al. [69] investigated whether the $-1516 \mathrm{G} / \mathrm{T},-574 \mathrm{G} / \mathrm{T}$ and $+4259 \mathrm{~T} / \mathrm{G}$ single-nucleotide polymorphisms (SNPs) in the TIM-3 gene contribute to genetic susceptibility to invasive breast cancer in the Northern China Han ethnicity and determined that the $+4259 \mathrm{~T} / \mathrm{G}$ SNP in the TIM-3 gene has an important role in breast cancer prognosis and progression.

TIM-3 and pancreatic cancer. Despite continued improvement in conventional therapy, the incidence of pancreatic cancer has increased in China in recent years and it is widely considered a top ten cause of cancer related mortality [70]. Peng et al. [71] observed that TIM-3 expression in pancreatic cancer tissues was elevated and statistically significant compared to local normal tissues. The high TIM-3 expression in the cancerous tissues was closely related to cell invasion, metastasis and recurrence. Tong et al. [72] then investigated the correlation of TIM-3 polymorphisms with susceptibility to pancreatic cancer in the Chinese population and identified that $+4259 \mathrm{TG}$ genotype and $+4259 \mathrm{G}$ allele prevalence were significantly higher in cancer than in controls. These results strongly suggest that TIM-3 gene polymorphisms are risk factors in pancreatic cancer development.

TIM-3 and prostate cancer. Prostate cancer is a heterogeneous disease and one of the most common malignancies in men and second-ranking in male cancer mortality [73]. The incidence is increasing annually [74], and advanced diagnostic techniques and effective markers are essential not only for early detection of this painless cancer but also to prevent over-treatment.

Piao et al. [6] showed that the expression of TIM-3 in prostate cancer was significantly higher than in adjacent benign tissues, and that TIM-3 is expressed in both DU145 and LNCap prostate cancer cell lines. However, while flow cytometry indicated that TIM-3 expression on CD4+T and $\mathrm{CD} 8+\mathrm{T}$ cells in prostate cancer patients was significantly higher than in those with benign prostatic hyperplasia, TIM-3 siRNA inhibited these cells' proliferation and invasion. The combined results suggest that TIM-3 has an important role in prostate cancer progression and invasion and may be one of the poor prognostic factor for these patients. Previously, Yuan et al. [75] confirmed the prognostic effect of TIM-3 on renal clear cell carcinoma using the same method, so the results are consistent. In summary, TIM-3 has an important role in the proliferation and invasion of prostate cancer cells and can be used as an indicator of poor prognosis.
TIM-3 and ovarian cancer. Ovarian cancer is the most lethal gynecological cancer and the fifth leading cause of cancer death in American women [76]. Over 70\% of ovarian cancer women had advanced tumor cells throughout the peritoneal cavity [77], and although there is surgical resection and radiotherapy combined with chemotherapy, its efficacy is limited by drug resistance [78]. There is therefore urgent need to develop new treatment options.

$\mathrm{Wu}$ et al. [7] analyzed expression of TIM-3 in peripheral blood CD4+ T and CD8+ T cells in 53 ovarian cancer patients and 56 healthy controls by flow cytometry. Results established that TIM-3 expression in peripheral blood CD4+ $\mathrm{T}$ and CD8+ $\mathrm{T}$ cells was significantly higher than in healthy controls and the TIM-3+ CD4+ T cells were more numerous in recurrent patients than in newly diagnosed patients. The expression level of TIM-3 in CD4+ T and CD8+ T cells in III/ IV stage patients was also significantly higher than in stages I/II, and this expression in well differentiated patients was higher than in poorly differentiated patients.

Studies have also shown that TIM-3 may be involved in the development and progression of ovarian cancer as a negative regulator of T cell subsets, and the TIM-3 expression on CD4+ T cells may therefore be a predictor of antitumor therapeutic effect. Guo et al. [50] then injected the anti-TIM-3 and anti-CD137 antibody into ovarian cancer models and this significantly inhibited $60 \%$ tumor growth within 10 days in the mouse model. While these mice survived 90 days, separate administration of anti-TIM-3 or anti-CD137 antibody could only inhibit this in 3 days, and this procedure in the rat model also proved ineffective within 10 days.

This combination of the two antibodies increased the number of $\mathrm{CD} 4+\mathrm{T}, \mathrm{CD} 8+\mathrm{T}$ cells in tumor tissue and reduced the number of immunosuppressive Treg and MDSC cells. Consequently, the proportion of CD4+ T, CD8+ T and MDSC significantly increased and immune response was enhanced. In summary, TIM-3 has a very important role in ovarian cancer development and progression, and it may therefore prove successful as a new therapeutic target in ovarian cancer.

TIM-3 and cervical cancer. Cervical cancer in women ranks second only to breast cancer, and new instances are constantly increasing. This is despite the knowledge that this tumor is one of the most easily preventable malignancies of all [79].

Cao et al. [80] found that TIM-3 was preferentially expressed in cervical cancer cells compared to intra-cortical neoplasia (CIN) and chronic cervicitis. Patients with high TIM-3 expression also had higher metastatic potential, higher tumor grade and lower survival rate than those with low expression. Meanwhile, ADV-antisense TIM-3 downregulated TIM-3 expression in HeLa cells and inhibited their ability to metastasize and invade. TIM-3 inhibited the CD4+T lymphocyte activity and promoted tumor metastasis by activating the IL-6-STAT3 signaling pathway. This 
study implies that TIM-3 can inhibit cellular immunity and promote tumor metastasis through the IL-6-STAT3 signaling pathway, and that TIM-3 could be a useful independent prognostic indicator in cervical cancer.

\section{Conclusion}

Our study of TIM-3 expression and mechanisms in tumor patients confirmed that TIM-3 has a very important role in tumor immunity. TIM-3 can induce Th1 cell apoptosis, promote CD8+T cell depletion and promote both M2 macrophage polarization and myeloid-derived suppressor cell proliferation to suppress the immune response. This consequently develops the immuno-suppressive tumor microenvironment and leads to immune tolerance; with resultant tumor occurrence, development and poor prognosis. TIM-3 may therefore be a successful new target in tumor therapy because blocking the TIM-3 signaling pathway can modulate cellular immune response. This then inhibits tumor occurrence and development. Although TIM-3's precise mechanism and role in tumors is still not clear and requires further research, we believe that TIM-3 will become a new target in tumor therapy and that it will bring new hope to cancer treatment by further research.

Acknowledgments: This work was supported by the National Natural Science Foundation of China (No. 81760117 and No. 81460126). We thank LetPub (www.letpub.com) for its linguistic assistance during the preparation of this manuscript.

\section{References}

[1] ANNUNZIATO F, ROMAGNANI C, ROMAGNANI S. The 3 major types of innate and adaptive cell-mediated effector immunity. J Allergy Clin Immunol 2015; 135: 626-635. https://doi.org/10.1016/j.jaci.2014.11.001

[2] SAKUISHI K, JAYARAMAN P, BEHAR SM, ANDERSON AC, KUCHROO VK. Emerging Tim-3 functions in antimicrobial and tumor immunity. Trends Immunol 2011; 32: 345-349. https://doi.org/10.1016/j.it.2011.05.003

[3] FREEMAN GJ, CASASNOVAS JM, UMETSU DT, DEKRUYFF RH. TIM genes: a family of cell surface phosphatidylserine receptors that regulate innate and adaptive immunity. Immunol Rev 2010; 235: 172-189. https://doi. org/10.1111/j.0105-2896.2010.00903.x

[4] LI H, WU K, TAO K, CHEN L, ZHENG Q et al. Tim-3/galectin-9 signaling pathway mediates T-cell dysfunction and predicts poor prognosis in patients with hepatitis B virusassociated hepatocellular carcinoma. Hepatology 2012; 56: 1342-1351. https://doi.org/10.1002/hep.25777

[5] CHENG G, LI M, WU J, JI M, FANG C et al. Expression of Tim-3 in gastric cancer tissue and its relationship with prognosis. Int J Clin Exp Pathol 2015; 8: 9452-9457.

[6] PIAO YR, PIAO LZ, ZHU LH, JIN ZH, DONG XZ. Prognostic value of $\mathrm{T}$ cell immunoglobulin mucin-3 in prostate cancer. Asian Pac J Cancer Prev 2013; 14: 3897-3901.
[7] WU J, LIU C, QIAN S, HOU H. The expression of Tim-3 in peripheral blood of ovarian cancer. DNA Cell Biol 2013; 32: 648-653. https://doi.org/10.1089/dna.2013.2116

[8] JIANG J, JIN MS, KONG F, CAO D, MA HX et al. Decreased galectin- 9 and increased Tim-3 expression are related to poor prognosis in gastric cancer. PLoS One 2013; 8: e81799. https://doi.org/10.1371/journal.pone.0081799

[9] MCINTIRE JJ, UMETSU SE, AKBARI O, POTTER M, KUCHROO VK et al. Identification of Tapr (an airway hyperreactivity regulatory locus) and the linked Tim gene family. Nat Immunol 2001; 2: 1109-1116. https://doi.org/10.1038/ ni739

[10] KUCHROO VK, UMETSU DT, DEKRUYFF RH, FREEMAN GJ. The TIM gene family: emerging roles in immunity and disease. Nat Rev Immunol 2003; 3: 454-462. https://doi. org/10.1038/nri1111

[11] MONNEY L, SABATOS CA, GAGLIA JL, RYU A, WALDNER $\mathrm{H}$ et al. Th1-specific cell surface protein Tim-3 regulates macrophage activation and severity of an autoimmune disease. Nature 2002; 415: 536-541. https://doi. org/10.1038/415536a

[12] SANCHEZ-FUEYO A, TIAN J, PICARELLA D, DOMENIG C, ZHENG XX et al. Tim-3 inhibits T helper type 1-mediated auto- and alloimmune responses and promotes immunological tolerance. Nat Immunol 2003; 4: 1093-1101. https:// doi.org/10.1038/ni987

[13] DAS M, ZHU C, KUCHROO VK. Tim-3 and its role in regulating anti-tumor immunity. Immunol Rev 2017; 276: 97-111. https://doi.org/10.1111/imr.12520

[14] RODRIGUEZ-MANZANET R, DEKRUYFF R, KUCHROO VK, UMETSU DT. The costimulatory role of TIM molecules. Immunol Rev 2009; 229: 259-270. https://doi.org/10.1111/ j.1600-065X.2009.00772.x

[15] ZHU C, ANDERSON AC, SCHUBART A, XIONG H, IMITOLA J et al. The Tim-3 ligand galectin-9 negatively regulates T helper type 1 immunity. Nat Immunol 2005; 6: 1245 1252. https://doi.org/10.1038/ni1271

[16] IMAIZUMI T, KUMAGAI M, SASAKI N, KUROTAKI H, MORI F et al. Interferon-gamma stimulates the expression of galectin-9 in cultured human endothelial cells. J Leukoc Biol 2002; 72: 486-491.

[17] SABATOS CA, CHAKRAVARTI S, CHA E, SCHUBART A, SANCHEZ-FUEYO A et al. Interaction of Tim-3 and Tim3 ligand regulates $\mathrm{T}$ helper type 1 responses and induction of peripheral tolerance. Nat Immunol 2003; 4: 1102-1110. https://doi.org/10.1038/ni988

[18] CHIBA S, BAGHDADI M, AKIBA H, YOSHIYAMA H, KINOSHITA I et al. Tumor-infiltrating DCs suppress nucleic acid-mediated innate immune responses through interactions between the receptor TIM-3 and the alarmin HMGB1. Nat Immunol 2012; 13: 832-842. https://doi.org/10.1038/ ni. 2376

[19] MATTEI F, SCHIAVONI G. TIM-3 as a molecular switch for tumor escape from innate immunity. Front Immunol 2012; 3: 418. https://doi.org/10.3389/fimmu.2012.00418

[20] TANG D, LOTZE MT. Tumor immunity times out: TIM-3 and HMGB1. Nat Immunol 2012; 13: 808-810. https://doi. org/10.1038/ni.2396 
[21] BANERJEE H, KANE LP. Immune regulation by Tim-3. F1000Res 2018; 7: 316. https://doi.org/10.12688/f1000research.13446.1

[22] ANTONY PA, PICCIRILLO CA, AKPINARLI A, FINKELSTEIN SE, SPEISS PJ et al. CD8+ T cell immunity against a tumor/self-antigen is augmented by $\mathrm{CD} 4+\mathrm{T}$ helper cells and hindered by naturally occurring T regulatory cells. J Immunol 2005; 174: 2591-2601. httpss://doi.org/10.4049/jimmunol.174.5.2591

[23] RAMAKRISHNAN R, ASSUDANI D, NAGARAJ S, HUNTER T, CHO HI et al. Chemotherapy enhances tumor cell susceptibility to CTL-mediated killing during cancer immunotherapy in mice. J Clin Invest 2010; 120: 1111-1124. https:// doi.org/10.1172/JCI40269

[24] PAUKEN KE, WHERRY EJ. Overcoming T cell exhaustion in infection and cancer. Trends Immunol 2015; 36: 265-276. https://doi.org/10.1016/j.it.2015.02.008

[25] MCKINNEY EF, LEE JC, JAYNE DR, LYONS PA, SMITH KG. T-cell exhaustion, co-stimulation and clinical outcome in autoimmunity and infection. Nature 2015; 523: 612-616. https://doi.org/10.1038/nature14468

[26] KIM PS, AHMED R. Features of responding T cells in cancer and chronic infection. Curr Opin Immunol 2010; 22: 223230. https://doi.org/10.1016/j.coi.2010.02.005

[27] DARDALHON V, ANDERSON AC, KARMAN J, APETOH L, CHANDWASKAR R et al. Tim-3/galectin-9 pathway: regulation of Th1 immunity through promotion of CD11b+Ly6G+ myeloid cells. J Immunol 2010; 185: 1383-1392. https:// doi.org/10.4049/jimmunol.0903275

[28] ZHOU Q, MUNGER ME, VEENSTRA RG, WEIGEL BJ, HIRASHIMA $M$ et al. Coexpression of Tim-3 and PD-1 identifies a CD8+ T-cell exhaustion phenotype in mice with disseminated acute myelogenous leukemia. Blood 2011; 117: 4501-4510. https://doi.org/10.1182/blood-2010-10-310425

[29] NGIOW SF, von SCHEIDT B, AKIBA H, YAGITA H, TENG MW et al. Anti-TIM3 antibody promotes T cell IFN-gamma-mediated antitumor immunity and suppresses established tumors. Cancer Res 2011; 71: 3540-3551. https://doi. org/10.1158/0008-5472.CAN-11-0096

[30] KNUTSON KL, DISIS ML. Tumor antigen-specific T helper cells in cancer immunity and immunotherapy. Cancer Immunol Immunother 2005; 54: 721-728. https://doi. org/10.1007/s00262-004-0653-2

[31] ANDERSON AC. Tim-3, a negative regulator of anti-tumor immunity. Curr Opin Immunol 2012; 24: 213-216. https:// doi.org/10.1016/j.coi.2011.12.005

[32] YAN J, ZHANG Y, ZHANG JP, LIANG J, LI L et al. Tim3 expression defines regulatory $\mathrm{T}$ cells in human tumors. PLoS One 2013; 8: e58006. https://doi.org/10.1371/journal. pone. 005800

[33] GAUTRON AS, DOMINGUEZ-VILLAR M, de MARCKEN M, HAFLER DA. Enhanced suppressor function of TIM-3+ FoxP3+ regulatory T cells. Eur J Immunol 2014; 44: 27032711. https://doi.org/10.1002/eji.201344392

[34] HU G, LIU Z, ZHENG C, ZHENG SG. Antigen-non-specific regulation centered on CD25+Foxp3+ Treg cells. Cell Mol Immunol 2010; 7: 414-418. https://doi.org/10.1038/ cmi.2010.39
[35] ABASTADO JP. The next challenge in cancer immunotherapy: controlling T-cell traffic to the tumor. Cancer Res 2012; 72 : 2159-2161. https://doi.org/10.1158/0008-5472.CAN-11-3538

[36] NISHIKAWA H, SAKAGUCHI S. Regulatory T cells in tumor immunity. Int J Cancer 2010; 127: 759-767. Int J Cancer 2010; 127: 759-767.

[37] NGIOW SF, TENG MW, SMYTH MJ. Prospects for TIM3Targeted Antitumor Immunotherapy. Cancer Res 2011; 71: 6567-6571. https://doi.org/10.1158/0008-5472.CAN-11-1487

[38] HASTINGS WD, ANDERSON DE, KASSAM N, KOGUCHI K, GREENFIELD EA et al. TIM-3 is expressed on activated human CD4+ T cells and regulates Th1 and Th17 cytokines. Eur J Immunol 2009; 39: 2492-2501. https://doi. org/10.1002/eji.200939274

[39] LANGOWSKI JL, ZHANG X, WU L, MATTSON JD, CHEN T et al. IL-23 promotes tumour incidence and growth. Nature 2006; 442: 461-465. https://doi.org/10.1038/nature04808

[40] MOSSER DM. The many faces of macrophage activation. J Leukoc Biol 2003; 73: 209-212.

[41] JIANG X, YU J, SHI Q, XIAO Y, WANG W et al. Tim-3 promotes intestinal homeostasis in DSS colitis by inhibiting M1 polarization of macrophages. Clin Immunol 2015; 160: 328-335. https://doi.org/10.1016/j.clim.2015.07.008

[42] HUME DA. The Many Alternative Faces of Macrophage Activation. Front Immunol 2015; 6: 370. https://doi.org/10.3389/ fimmu.2015.00370

[43] ZHANG Y, MA CJ, WANG JM, JI XJ, WU XY et al. Tim-3 regulates pro- and anti-inflammatory cytokine expression in human CD14+ monocytes. J Leukoc Biol 2012; 91: 189-196. https://doi.org/10.1189/jlb.1010591

[44] PATEL J, BOZEMAN EN, SELVARAJ P. Taming dendritic cells with TIM-3: another immunosuppressive strategy used by tumors. Immunotherapy 2012; 4: 1795-1798. https://doi. org/10.2217/imt.12.126

[45] JINUSHI M. Regulatory mechanisms of nucleic acid-mediated innate immune responses in the tumor microenvironment. Oncoimmunology 2012; 1: 1632-1634. https://doi. org/10.4161/onci.21681

[46] ANDERSON AC, ANDERSON DE, BREGOLI L, HASTINGS WD, KASSAM N et al. Promotion of tissue inflammation by the immune receptor Tim-3 expressed on innate immune cells. Science 2007; 318: 1141-1143. https://doi. org/10.1126/science.1148536

[47] NAGAHARA K, ARIKAWA T, OOMIZU S, KONTANI K, NOBUMOTO A et al. Galectin-9 increases Tim-3+ dendritic cells and CD8+ T cells and enhances antitumor immunity via galectin-9-Tim-3 interactions. J Immunol 2008; 181: 7660-7669. httpss://doi.org/10.4049/jimmunol.181.11.7660

[48] HUANG X, BAI X, CAO Y, WU J, HUANG M et al. Lymphoma endothelium preferentially expresses Tim-3 and facilitates the progression of lymphoma by mediating immune evasion. J Exp Med 2010; 207: 505-520. https://doi. org/10.1084/jem.20090397

[49] DARDALHON V, ANDERSON AC, KARMAN J, APETOH L, CHANDWASKAR R et al. Tim-3/galectin-9 pathway: regulation of Th1 immunity through promotion of CD11b+Ly6G+ myeloid cells. J Immunol 2010; 185: 1383-1392. https:// doi.org/10.4049/jimmunol.0903275 
[50] GUO Z, CHENG D, XIA Z, LUAN M, WU L et al. Combined TIM-3 blockade and CD137 activation affords the long-term protection in a murine model of ovarian cancer. J Transl Med 2013; 11: 215. https://doi.org/10.1186/1479-5876-11-215

[51] FOURCADE J, SUN Z, BENALLAOUA M, GUILLAUME P, LUESCHER IF et al. Upregulation of Tim-3 and PD-1 expression is associated with tumor antigen-specific CD8+ T cell dysfunction in melanoma patients. J Exp Med 2010; 207: 2175-2186. J Exp Med 2010; 207: 2175-2186.

[52] ARAI Y, SAITO H, IKEGUCHI M. Upregulation of TIM-3 and PD-1 on CD4+ and CD8+ T Cells Associated with Dysfunction of Cell-Mediated Immunity after Colorectal Cancer Operation. Yonago Acta Med 2012; 55: 1-9.

[53] SAKUISHI K, APETOH L, SULLIVAN JM, BLAZAR BR, KUCHROO VK et al. Targeting Tim-3 and PD-1 pathways to reverse $\mathrm{T}$ cell exhaustion and restore anti-tumor immunity. J Exp Med 2010; 207: 2187-2194. https://doi.org/10.1084/ jem. 20100643

[54] FOURCADE J, SUN Z, PAGLIANO O, CHAUVIN JM, SANDER $C$ et al. PD-1 and Tim-3 regulate the expansion of tumor antigen-specific CD8(+) T cells induced by melanoma vaccines. Cancer Res 2014; 74: 1045-1055. https://doi. org/10.1158/0008-5472.CAN-13-2908

[55] HUANG YH, ZHU C, KONDO Y, ANDERSON AC, GANDHI A et al. CEACAM1 regulates TIM-3-mediated tolerance and exhaustion. Nature 2015; 517: 386-390. https://doi. org/10.1038/nature13848

[56] PARDOLL DM. The blockade of immune checkpoints in cancer immunotherapy. Nat Rev Cancer 2012; 12: 252-264. https://doi.org/10.1038/nrc3239

[57] WOO SR, TURNIS ME, GOLDBERG MV, BANKOTI J, SELBY $\mathrm{M}$ et al. Immune inhibitory molecules LAG-3 and PD-1 synergistically regulate T-cell function to promote tumoral immune escape. Cancer Res 2012; 72: 917-927. https://doi. org/10.1158/0008-5472.CAN-11-1620

[58] FOURCADE J, SUN Z, PAGLIANO O, GUILLAUME P, LUESCHER IF et al. CD8(+) T cells specific for tumor antigens can be rendered dysfunctional by the tumor microenvironment through upregulation of the inhibitory receptors BTLA and PD-1. Cancer Res 2012; 72: 887-896. https://doi. org/10.1158/0008-5472.CAN-11-2637

[59] YU LX, LING Y, WANG HY. Role of nonresolving inflammation in hepatocellular carcinoma development and progression. NPJ Precis Oncol 2018; 2: 6. https://doi.org/10.1038/ s41698-018-0048-Z

[60] LI Z, LIU Z, ZHANG G, HAN Q, LI N et al. TIM3 gene polymorphisms in patients with chronic hepatitis B virus infection: impact on disease susceptibility and hepatocellular carcinoma traits. Tissue Antigens 2012; 80: 151-157. https:// doi.org/10.1111/j.1399-0039.2012.01898.x

[61] KARIM-KOS HE, de VRIES E, SOERJOMATARAM I, LEMMENS V, SIESLING S et al. Recent trends of cancer in Europe: a combined approach of incidence, survival and mortality for 17 cancer sites since the 1990s. Eur J Cancer 2008; 44: 1345-1389. https://doi.org/10.1016/j.ejca.2007.12.015
[62] FORMAN D, BURLEY VJ. Gastric cancer: global pattern of the disease and an overview of environmental risk factors. Best Pract Res Clin Gastroenterol 2006; 20: 633-649. https:// doi.org/10.1016/j.bpg.2006.04.008

[63] CAO B, ZHU L, ZHU S, LI D, ZHANG C et al. Genetic variations and haplotypes in TIM-3 gene and the risk of gastric cancer. Cancer Immunol Immunother 2010; 59: 1851-1857.

[64] HONG QY, WU GM, QIAN GS, HU CP, ZHOU JY et al. Prevention and management of lung cancer in China. Cancer 2015; 121 Suppl 17: 3080-3088. https://doi.org/10.1002/ cncr.29584

[65] JI P, CHEN D, BIAN J, XIA R, SONG X et al. [Up-regulation of TIM-3 on CD4+ tumor infiltrating lymphocytes predicts poor prognosis in human non-small-cell lung cancer]. Xi Bao Yu Fen Zi Mian Yi Xue Za Zhi 2015; 31: 808-811.

[66] GAO J, QIU X, LI X, FAN H, ZHANG F et al. Expression profiles and clinical value of plasma exosomal Tim-3 and Galectin-9 in non-small cell lung cancer. Biochem Biophys Res Commun 2018; 498: 409-415. https://doi.org/10.1016/j. bbrc.2018.02.114

[67] ZHU S, LIN J, QIAO G, WANG X, XU Y. Tim-3 identifies exhausted follicular helper T cells in breast cancer patients. Immunobiology 2016; 221: 986-993. https://doi.org/10.1016/j. imbio.2016.04.005

[68] SHEN H, SHENG H, LU JJ, FENG C, YAO M et al. [Expression and distribution of programmed death receptor 1 and $\mathrm{T}$ cell immunoglobulin mucin 3 in breast cancer microenvironment and its relationship with clinicopathological features]. Zhonghua Yi Xue Za Zhi 2018; 98: 1352-1357. https://doi.org/10.3760/cma.j.issn.0376-2491.2018.17.014

[69] CHENG S, JU Y, HAN F, WANG Y, XU Y et al. T Cell Immunoglobulin- and Mucin-Domain-Containing Molecule 3 Gene Polymorphisms and Susceptibility to Invasive Breast Cancer. Ann Clin Lab Sci 2017; 47: 668-675.

[70] CHEN W, ZHENG R, BAADE PD, ZHANG S, ZENG H et al. Cancer statistics in China, 2015. CA Cancer J Clin 2016; 66: 115-132. https://doi.org/10.3322/caac.21338

[71] PENG PJ, LI Y, SUN S. On the significance of Tim-3 expression in pancreatic cancer. Saudi J Biol Sci 2017; 24: 17541757. https://doi.org/10.1016/j.sjbs.2017.11.006

[72] TONG D, ZHOU Y, CHEN W, DENG Y, LI L et al. T cell immunoglobulin- and mucin-domain-containing molecule 3 gene polymorphisms and susceptibility to pancreatic cancer. Mol Biol Rep 2012; 39: 9941-9946. https://doi.org/10.1007/ s11033-012-1862-y

[73] WONG MC, GOGGINS WB, WANG HH, FUNG FD, LEUNG $\mathrm{C}$ et al. Global Incidence and Mortality for Prostate Cancer: Analysis of Temporal Patterns and Trends in 36 Countries. Eur Urol 2016; 70: 862-874. https://doi. org/10.1016/j.eururo.2016.05.043

[74] SUGIYAMA Y, MASUMORI N, FUKUTA F, YONETA A, HIDA $T$ et al. Influence of isoflavone intake and equol-producing intestinal flora on prostate cancer risk. Asian Pac J Cancer Prev 2013; 14: 1-4.

[75] YUAN J, JIANG B, ZHAO H, HUANG Q. Prognostic implication of TIM-3 in clear cell renal cell carcinoma. Neoplasma 2014; 61: 35-40. https://doi.org/10.4149/neo_2014_006 
[76] DIXON SC, NAGLE CM, WENTZENSEN N, TRABERT B, BEEGHLY-FADIEL A et al. Use of common analgesic medications and ovarian cancer survival: results from a pooled analysis in the Ovarian Cancer Association Consortium. Br J Cancer 2017; 116: 1223-1228. https://doi.org/10.1038/ bjc. 2017.68

[77] LEARY A, PAUTIER P, TAZI Y, MORICE P, DUVILLARD $P$ et al. [The molecular biology of epithelial ovarian cancer]. Bull Cancer 2012; 99: 1161-1173. Bull Cancer 2012; 99: 1161-1173.
[78] WEI H, HELLSTROM KE, HELLSTROM I. Elafin selectively regulates the sensitivity of ovarian cancer cells to genotoxic drug-induced apoptosis. Gynecol Oncol 2012; 125: 727-733. https://doi.org/10.1016/j.ygyno.2012.03.018

[79] PETRY KU. HPV and cervical cancer. Scand J Clin Lab Invest Suppl 2014; 244: 59-62. https://doi.org/10.3109/003655 13.2014 .936683

[80] CAO Y, ZHOU X, HUANG X, LI Q, GAO L et al. Tim-3 expression in cervical cancer promotes tumor metastasis. PLoS One 2013; 8: e53834. PLoS One 2013; 8: e53834. https://doi. org/10.1371/journal.pone.0053834 